\title{
Corporate Social Responsibility and Ethical Banking for Developing Economies
}

\author{
N Dorasamy \\ Durban University of Technology, KwaZulu-Natal, South Africa \\ nirmala@dut.ac.za
}

\begin{abstract}
Corporate social responsibility is being increasingly considered vital for organizational success and sustainable growth, especially in view of corporations operating in an environment with multiple stakeholder interests. Investment in CSR should not been seen as an expense, but rather the allocation of resources to strengthen relationships with stakeholders in an endeavour to reap the multifaceted benefits of such investments Financial institutions like banks need to be seen as leading organizations who engage in social activities that uplift society, the environment and economy. The article analyses significant areas of corporate social responsibility for banks which are integral for customers, government, suppliers, citizens, employees and global partners for enhancing the responsibility of banks to a diverse range of stakeholders who have an interest in the banks. This 'common good' reputation can provide several advantages to banks which further impacts on the performance of banks.
\end{abstract}

Keywords: Corporate social responsibility, ethical banking, developing economies, stakeholder interests

\section{Introduction}

Banks are obligated to satisfy a diverse range of stakeholders. Banks are expected to maximize profits for shareholders who contributed funds toward their establishment. It has to maintain adequate liquidity to meet the demands of depositors. Apart from being obliged to satisfy the legitimate requests for credit, banks also need to comply with regulatory requirements to do business. Overall, banks need to be seen as good corporate citizens who contribute to the maximum development of the economy and society (Nkwankwo, 1991:26). These complex relationships with different stakeholders have made corporate social responsibility and the existence of banks interdependent and inseparable. Banks need to be socially responsible to be able to build their "reputational capital", thereby enabling them to attract high quality employees, negotiate better contracts, expand their customer base, attract investors and win public trust and confidence (Achua, 2012:59). Banks play a critical role in financial and economic development, especially in developing countries which are rapidly expanding. Since their importance has grown over the years, banks need to fulfill their ethical role as financial institutions operating in different contexts. In developing countries, where the social and economic challenges are generally felt most, banks have a huge corporate social responsibility. This is exacerbated by the global crisis which placed greater responsibility on banks to ensure that their financial management systems do not negatively impact on society. Institutions like the World Bank, International Monetary Fund, Global Reporting Initiative and Equator Principles increasingly seek to promote CSR policies and practices, especially in developing countries. In addition, government policy is valuable in improving CSR among banks. Corporate social responsibility is importantly directed toward developing and sustaining the social responsibility of economic and financial institutions.

Generally, the common themes relating to corporate social responsibility (CSR) include: responsible behaviour, environmental issues, sustainable development and social conduct. In pricing and valuing financial assets, monitoring borrowers, managing financial risks and organizing various means of payment, banks impact on society. Therefore, they need to adopt CSR as corporate citizens, since in the era of the global recession it is the welfare of the community that is gaining importance against the broader concept of organizational success (Ali, Rehman, Ali, Yousaf and Zia, 2010:2796). In this regard, Argandona (1998:1094) argues that institutions like banks which have a purpose in society must be aware of what 'society' is, what it does for them and what it needs from them. Therefore, the common good of banks is to fulfil their purpose as banks which would enable all stakeholders to achieve what each reasonably expects. The increase in the number of banks in developing economies has led to increased competition in the banking system as well as the introduction of more innovative and sophisticated banking products (Tantawi and Youssef, 2012:13). This development is important especially in view of the social, economic and political dilemmas which affected trust and confidence in many financial institutions (Aggarwal and Youssef, 2003:95). In view of this, international lending organizations like the 
World Bank exert increasing pressure on banks to exercise CSR practices, since emerging economies generally depend on foreign loans and aid. Since widespread poverty, human rights violations, corruption, inequalities and social exploitations are common in such economies, CSR is a vital consideration of banks. Being socially responsible is becoming a focus among banks since their reputation is judged on their CSR policies and programmes.

The practice of Islamic banking principles is worthy of mention. The acknowledgement of Islamic banking and finance (IBF) by the International Financial system has encouraged non-Muslim countries to practice Islamic finance, believing it to be a future market leader (Nor, 2012:138). It is therefore important that banks in building their identity and place in society need to not only be concerned with their own interests and legal requirements, but also with the satisfaction of the expectations of all stakeholders. This creates an imperative for banks in developing economies to engage in financial practices that will address problems like reckless financial attitudes, decline in moral values, environmental destruction, poverty and unemployment. Tantawi and Youssef (2012:79) refer to the adoption of a "profit maximizing" CSR approach, whereby institutions anticipate benefiting financially by being socially responsible. Such an approach is reflected in high quality services or products associated with CSR, which differentiates the ethical bank from other banks. Therefore, while banks are concerned with their main interests, they should also make concerted efforts to satisfy stakeholder expectations to avoid being condemned for embracing CSR as mere lip service (Cowton, 2010:135). Rahaman, Lawrence and Roper (2004:40) contend that such efforts in emerging economies are driven by outside forces like pressure from international financial institutions. The authors argue that external pressure can promote passive compliance without effective internal corporate accountability and transparency. Therefore, a cultural change is required in such cases so that banks are not guilty of superficially applying CSR activities. Lantos (2001 in Jamali, 2007:5) argued that ethical CSR is morally mandatory for institutions to avoid social harm even if they do not benefit directly. Lantos believed that this level of fulfilment of social responsibility is what is generally expected in the context of morality. However, Lantos (2001 in Jamali, 2007:6) considered altruistic CSR as optimal genuine concern for societal problems in an attempt to enhance the quality of life of all stakeholders. Businesses that practice altruistic CSR go beyond ethical CSR which is morally mandated, to assuming responsibility for societal problems that they have not initiated.

The model of Lantos, which views altruistic responsibility as "voluntarism", is seen as socially responsible social action that goes beyond ethical responsibility (Jamali, 2007:7). This merits recognition, since banks should not only fulfill their ethical responsibilities as morally responsible agents, but also engage further in voluntary social responsibility which begins where ethical responsibility ends. This is further extended in Ackerman's (1973:97) argument that social issues, which may be directly or indirectly related to an institution, can draw on corporate responsiveness which should be seen as anticipatory and not merely reactive. However, to avoid compromising economic performance through altruistic CSR, Lantos (2001 in Jamali, 2007:8) identified strategic CSR which aligns strategic business goals with societal welfare. In this respect, banks can identify activities that benefit the business and society through long-term investments, thus promoting win-win outcomes. Through the reconciliation of social and economic benefits, gain can be in the form of new business opportunities as well as increased goodwill and philanthropic practice for the benefit of all stakeholders. According to Jamali (2007:22), this offers prospects of greater credibility and added value. Some may regard this as self-serving and insincere, but Jamali argues that strategic CSR is more pragmatic in developing countries. The fundamental idea of CSR is that institutions have an obligation to meet the needs of a range of stakeholders as part of a commitment to contribute to sustainable economic development, working with employees and local communities (World Business Council for Sustainable Development, 2001:25).

The aims of ethical banking extend beyond economic benefits to include social objectives in terms of the triple bottom line including people, planet and profit (San-Jose, Retoloza and Gutierrez-Goiria, 2011:151). Ethical banks provide a high level of transparency and more detailed information to their stakeholders with regard to where money has been lent. Since the relationship between banks and their stakeholders is based on trust that demands ethical behaviour from banks, banks are obliged to show responsibility in terms of integrity, responsibility and affinity. In this sense, San-Jose et al. (2011:153) elaborate on the following three levels of responsibilities.

- Integrity -banks should not operate on exclusivity by excluding individuals or groups because of poverty, ethnicity or affiliations. 
- Responsibility - banks should be accountable for the social and economic consequences of their behaviour.

- Affinity - banks should adopt positive criteria in investments.

In terms of CSR, ethical banking is driven by self-regulation to achieve optimum ethical outcomes. SanJose et al. (2011:154) argue that stakeholders share a mission which takes a social and ethical direction. In terms of affinity, banks should contribute to building a society that matches shareholders interests through the responsible investment of their funds, while trying to optimize the interests of the majority of stakeholders. This requires transparency from banks, so that stakeholders can monitor their ethical considerations and consolidate their trust in banks. Which banks show commitment to equal opportunities, they accept responsibility for making high-risk investments without the normal guarantee mechanisms? As an ethical response, banks can develop alternative guarantee systems to promote investments in social projects which cannot provide traditional guarantees. Further, San-Jose et al. (2011:159) argue that for banks to be ethical, they ought to first place their assets in projects which have positive social added value and should be seen from a global perspective. The study by San Jose et al. (2011:159) highlighted that ethical banks exhaustively disclose information about the type of credit they give, the aim of the project and other features of investments by them. The study further revealed that ethical banks make every effort to invest their money in positive projects with added social value, while making this information public. Corporate responsibility has different dimensions which need to be considered individually by banks in determining their impact on organizational success.

\section{Responsible behaviour}

Responsible behaviour from banks requires social reporting. Several regulatory institutions like the World Bank and Equator Principles have strongly supported the development and adoption of CSR reporting standards. A study by Hu and Scholtens (2012:7) further added that reporting about CSR and signing up to international standards are a rare practice among banks in developing countries. Farook, Hassan and Lantis (2011:111) argue that CSR disclosure should not be driven by economic incentives or merely to construct a reality based on religious principles. Rather, they content that a strong ethical identity supporting CSR should be underpinned by subscribing to the religious reality and its obligations. Farook et al. (2011:120) further believe that mere compliance with society's expectations is not enough, since legitimacy can be threatened if institutions have failed to make disclosures about compliance with such expectations. The Egyptian populace, who are mainly Islamic, expect any institution like banks to show evidence of the discharge of their obligations and responsibilities, thereby earning legitimacy for their continued existence. Further, well informed stakeholders are increasingly demanding clear and hard facts about the social and environmental performance of banks, since banking is regarded as too important and sensitive to be left to bankers alone (Achua 2012:58).

Effective and responsible monitoring requires sound monitoring mechanisms. This ensures monitoring of innovations in banking practice by focusing on the bank's memorandum and articles of association, its contracts and financial reports. For example, Islamic banks are subjected to such external auditing by Shari'ah Supervisory Boards (SSB) which has a right to mandate CSR activities and disclosure. While the SSB may have a role in mandating decisions, this is largely determined by the nature of its monitoring functions on behalf of investors. For example, if banks have additional monitoring mechanisms to improve their internal control, then SSBs may not emphasize additional CSR disclosures. Reporting on CSR activities is an important aspect of monitoring. In developing economies, especially where there are high levels of corruption, transformation has to move toward more ethical considerations within the banking sector in an endeavour to drive efficient risk management affecting all stakeholders. A history of greed and materialism has led to irresponsible actions and disregard for ethical values in business transactions. Since the very nature of ethics from a business perspective stipulates a moral economy, banking is expected to fulfill such aspirations.

The liquidation of banks has a social impact on society, as it leads to a loss of national income and the wastage of scarce resources. When banks are distressed, they generally use much of the scarce resources that could have been invested into the production of other goods and services in the economy (Joseph and Maria, 2012:2). While banks need profit to survive, the profit is also needed for a healthy and stable economy. When banks lose profit, not only does it place society in distress, but it also erodes public confidence (Achua, 2012:61).In terms of social responsibility disclosure, several studies have found that disclosure relating to environmental impact was minimal (Branco and Rodrigues, 2006:233). Further, 
when disclosures are made on CSR, businesses which only use annual reports as a medium of communication are generally criticized. While annual reports have a degree of credibility, the authors argue that they should be complemented by other social media. A study by Murray and Vogel (1997 in McDonald and Rundle -Thiele, 2008:4) found that reporting on combined programmes like socially responsible business practices; training programmes; promotions; community volunteering; proenvironmental and pro-economic factors; and consumer protection resulted in improved attitudes toward businesses, including beliefs about the business's honesty, consumer responsiveness and increased support for such businesses in labour disputes. Sen and Bhattacharya's (2001:239) research further supported the suggestion that a business' efforts in different CSR categories had a positive impact on customer evaluations.

\section{Environmental issues}

By adopting codes, publishing sustainability reports and implementing an environmental management system, it can be asserted that a bank commits to CSR. Taking care of the environment is also shown in ways in which banks take responsibility for environmental risks. In recent years, the ownership of organizations across the world has impacted on the development of corporate governance which is more transparent and accountable. In developing states especially, environmental awareness among institutions like banks is still in its infancy phase. The risk aversion theory purports that rational investors search for efficient investment as a means to reduce potential risk. Therefore, by choosing a socially responsible institution, which has a credible environmental record, potential risk is reduced (Mallin, 1999 in Wahba, 2008:362).A study by Hu and Scholtens (2012:7) showed that while many banks appear to have an environmental policy, they do seem to filter through to management systems or policy implementation. This does not anger well if banks want to increase their market value as several studies have found a positive relationship between environmental initiatives and higher profitability (Spicer, 1978; Schietz and Epstein, 2005; White, 1996 in Wahba, 2008:363). In other words, if banks invest more in establishing their environmental reputation, then they can attract more investors.

Conversely, the myopic institution theory states that since managers are evaluated based on short-term results, investors can be considered as short-sighted investors who are concerned only with short term results. This theory considers investment in environmental initiatives as long term which needs time to gain cost savings (Hansen and Hill, 1991; Graves and Waddock, 1994; Hart and Ahusa, 1996 in Wahba, 2008:363). This assertion does not consider higher investments in environmental initiatives as being able to attract more investors. Further, Coffey and Fryxell (1991 in Wahba, 2008:364) contend that the influence of economic criteria on investment activity supersedes social criteria on investment activity. However, when data relating to environmental responsibility is presented in financial form, then they have a positive influence (Teoh and Shiu, 1990:73). This then implies that since socially responsible investors are not interested in being penalized for unethical choices, institutions have to ensure that corporate environmental responsibility positively contributes to financial performance. A study by Wahba (2008:367) concluded that investors in the Egyptian context are best associated with the myopic institution theory since they are short-term oriented. Any attempt to have them away from this orientation will require strong financial motivations for environmental initiatives so that investments are not merely for tokenism. This is important since markets accord great value to corporate environmental responsibility, which does not harm ethical investment or financial performance.

By comparison with other sectors such as agriculture and manufacturing, banks have a lower direct environmental impact. However, Domench (2003 in Branco and Rodrigues, 2006:233) argues that banks, as facilitators of primary and secondary activities which cause environmental damage, need to consider environmentally sensitive issues in their policies and practices. Therefore, banks should be obliged to ensure that their lending and investment policies do not facilitate activities which are harmful to the environment. Branco and Rodrigues (2006:233) cite the example of banks establishing policies relating to the conservation of energy and natural resources, since they are large consumers of paper and energy. Scholtens (2008:663) further illustrates that the supply and development of green or socially responsible financial products is another way in which banks can show their commitment to sustainable development. These can include financial products that aim at reducing greenhouse gases. Through the evaluation of the non-financial characteristics of the policies of banks, investors can manage their funds that are consistent with the investors' mission and values. Further, this allows investors to make a tradeoff between the performances and policies of banks with respect to these factors and its financial performance (Scholtens, 2008:161). 


\section{Sustainable development}

Sustainable development by banks is underpinned by responsibility linked to CSR. According to Carroll (2000:35), one of the responsibilities that comprise CSR is the economic responsibility of businesses to be profit-making enterprises. It is an important motivation and compensation to reward stakeholders who take on commercial risk. Due to the impact of global trade, the economic responsibility by banks becomes a significant challenge in various types of competitive markets. Linked to the economic responsibility of banks is their economic role under certain laws and regulations. Even through the law may be inadequate to embrace "codified ethics" in its totality; it does provide basic notions of fairness and business righteousness (Carroll, 2000:35). In moving beyond codified laws, banks need to embrace practices that do not negatively impact on society by recognizing the needs of all stakeholders in a fair, right and just way. Apart from the economic, legal and ethical responsibilities of banks, society expects them to engage in social activities not mandated by law or expected in an ethical sense. Ultimately, banks affect sustainable development, since they need to meet the needs of the present without jeopardizing future generations from fulfilling their own needs (World Commission on Environment and Development, 1987 in Scholtens, 2008:159).

A study by Hu and Scholtens $(2012 ; 7)$ revealed that product development within the realm of CSR is still in its infancy in developing countries. Islamic banks in developing states like Egypt are a viable means of contracting for investors and fund users who support compliance with the laws and principles of Islam. There are "relevant publics" on which banks rely for support and should demonstrate adherence to the expectations of such supporters (Farook et al. 2011:122). However, the power of these "relevant publics" can influence the activities of banks to legitimize their actions to this group who have a powerful position in the social and political environment in which banks operate. A study by Farook et al. (2011:133) revealed that the level of influence of the "relevant publics" will impact on the CSR activities and disclosure of banks. Banks in Islamic states act as agents for investment account holders and shareholders. Farook et al. (2011:121) indicate that the investment account holders and shareholders often have inferior information available to them and often there is a bilateral dependency, whereby they depend on each other for monitoring the activities of the bank. By ensuring higher levels of monitoring, there is a greater chance of compliance with laws and principles. However, in countries where there is political and civil repression the influence of various bodies in monitoring may decrease. Such repression may weaken the capacity of monitoring bodies to voice their concerns regarding ethical organizational conduct. Further, such a political and social environment does not promote a need to justify the legitimate existence of banks and hence there is no obligation to disclose CSR information. It can be suggested that if monitoring initiatives are weakened, then the flow of information is ultimately weakened which invariably impacts on the level of CSR disclosure by banks.

A study by Farook et al. (2011:133) revealed that the nature of corporate governance, which is driven by economic and political realities, can influence greater monitoring and hence higher levels of CSR disclosure. The rights of investors and shareholders can be reflected in a corporate governance approach that adopts CSR disclosure in an attempt to bond with investors and shareholders and increase their confidence. By doing so, banks create desirable associations, attract view investments and create a positive success reputation (Tantawi and Youssef, 2012:81). Thus can lead to wider economic, social and cultural benefits which are vital for the long term sustainability of banks. Jamali and Mirshak (2007:244) consider CSR as a transition from mere compliance to a mode of engagement. Since banks significantly contribute to growth and value, they have an obligation to contribute to sustainable growth and opportunity. Nor (2012:145) asserts that moral economy, which is normally associated with the values of justice, fairness and equity which shape economic and financial activity, promotes social justice. He believes that in reality this principle which is closely aligned to the Islamic economy has not contributed which toward development in Muslim countries (2012:145). Had this been the case, Nor argues that there would have been more effective delivery of material benefits for the development of a moral economy. However, because of the overall focus being on purely maximizing profits, moral standards have been breached. This has resulted in fraud, violating human rights, pollution and misrepresentation among others. Nor (2012:146) argues for businesses adapting a tactical approach to CSR which entails operating beyond the legal requirements by pursuing a voluntary contribution to society and the environment. This argument is valid in that the recent financial crisis was largely due to the failure of good governance and risk management. 
Khan (2004 in Nor, 2012:146) considers the overlap of economic and social aspects as the "zone of sustainability" which is considered as an ideal framework for a moral banking system. However, achieving this ideal can be challenging in view of the diverse needs of society. A study by Sairally (2005 in Nor, 2012:147) found that while many Islamic banks undertake charitable activities, their activities do not contribute to developing the socio-economic capacities of the societies in which they operate. A further study by Dinar Standard and DaralIstithmar (2009 in Nor, 2012:147) found that while 77 percent of Islamic financial institutions around the globe consider charity as a priority deed, programmes for community development are yet to feature as a priority. In view of this, it can be argued that banks are not playing an active role to ensure CSR is practiced extensively beyond charity. If this is undertaken, then CSR will invariably extend to a wider sphere that sustains socio-economic growth. A study by Pomering and Donicar (2006) on CSR activities found that CSR initiatives that strongly favoured customers elicited the most positive attitudinal responses compared to those that benefited society; thereby concluding that customer's consideration for their own wellbeing may outweigh their consideration of broader social impacts. A study by McDonald and Rundle-Thiele (2008:9) highlighted that although creating customer satisfaction is not always the main reason for initiating CSR activities, CSR strategies linked to positive customer outcomes has led to the expectation that these strategies generally have positive impact on customers. The authors suggested the identification of a hierarchy of customer-preferred CSR initiatives to enable banks experiencing low customer satisfaction to review their CSR activities so that the broader community does not only benefit, but also customer satisfaction levels enjoy the benefits.

Social conduct: In terms of social conduct, Farook et al. (2011:119) view the relationship between individuals, organizations and society as a social contract. The existence of banks is legitimized by society and therefore has to operate within the boundaries established by their societies. Since they play a significant role in society, they have a responsibility to ensure that their activities do not negatively impact on the common good of society. In this respect, the importance of CSR can be linked to systemsoriented theories which emphasize the importance and influence of the social and political environments in which institutions operate. This requires banks to be self-regulators for observing social responsibility, since they have the power to exercise and respect social conduct ((Cassel, 2001:267).Banks being part of a system, need a value system that is congruent with the value system of the larger society in which it operates. This requires a level of accountability not only to the institution but also to society. This can be linked to Islamic principles of social justice based on obligatory payment out of income and wealth (zakah), philanthropic trusts (waaf), alms, charity (sadaqa) and interest free loans (qard-ul-hassan). These principles are consistent with CSR which requires "just distribution" of benefits so as to avoid undeserved loss (Farook et al., 2011:120). This is especially important for the disadvantaged who need assistance to emerge out of their situation by helping them to establish their own income generation opportunities, instead of merely finding their needs through charity (Farook et al., 2011:128). This is an important facet of CSR by banks whereby they disclose their accountability toward the disadvantaged.

In view of global transformation, customers expect banks to strive for a just, fair and balanced society. In view of Islamic banking gaining prominence worldwide it is worth noting that Islamic banking seeks to avoid practices that generate interest as incurred in the conventional banking system which is considered unjust to both borrowers and lenders, since the interest earned or paid by the bank is not commensurate with the actual performance of banks (Dusuki and Abdullah, 2007:144). Any form of earning interest is strictly avoided in the Islamic banking system. This invariably entails social justice and accountability, 'aimed at establishing distributive justice free from all sorts of exploitation'. Further, in keeping with the Islamic principles of brotherhood and co-operation, banks are expected to operate on the bases of equity sharing, risk sharing and stake taking. This is supported by the increasing growth of the ethical investment industry which is said to reap benefits from being ethical and responsible. Banks ought to be socially responsible since they are financial institutions, whose existence is condoned by society. Being part of a society entity contributing to public good, banks are obliged to promote honesty, integrity, accountability, responsibility and transparency among all members in society (Maali, Casson and Napier, 2003:60). This is necessary to establish the confidence of all stakeholders that all practices and policies are in accordance with the principles of social The idea of collectivism denotes broader responsibilities that will not only contribute toward moulding a better society which values social welfare, but is also dedicated to ensuring a better life for everyone (Nor, 2012:143). This is further extended to the principle of social justice, which requires adherence to values like rationality, fairness, equality and ethics that operate beyond the boundaries of law and regulation. Such conduct is crucial for a fair economic system that can contribute toward providing equal opportunity and just reward according to the effort made. 
Banks, which continuously interact with different spheres in the environment, confer a level of responsibility on them to society. The fact that society grants the legitimate and continued existence of banks as supported by the stakeholder theory, banks therefore have a social responsibility to all stakeholders for permitting their existence. Hence, banks need to optimize the economic satisfaction of all stakeholders, without exploiting the environment, depleting resources or violating human rights. Failure to do so can compromise economic and environmental sustainability, while highlighting a weak corporate social orientation and values. This is further reinforced by the United Nation Global Impact, which was launched at the Economic forum in 1999, whose objective is to uphold the triple bottom-line: make profit, car for the environment and uphold social justice. Several studies view employees as important stakeholders in any institution, since they are human resources who significantly contribute to organizational performance (Belal, 2008:125). Apart from employees, other stakeholders place their trust and confidence in institutions which focus on the salient principles of transparency and integrity in all facets of business relationships. While banks are under increasing pressure to rebuild public trust, they also have to remain profitable and innovative amidst business engagements that fulfill legal, ethical and societal expectations. This is aligned with the view that CSR is reflected in business being stewards of their own and public resources. In this regard, ethical responsibility of banks is important, not only as a necessary condition for profitable business management, but also in terms of economic and social justice (Milanzi, 1997 in Smurthwaite, 2011:81). Therefore, this entails exercising responsibility for fulfilling the social welfare demands that could influence society's life. This has become an obligation since corporate social responsibility can be considered as a license for businesses to operate, and without it their future can be at stake (Zinkin, 2004 in Nor, 2012:139).

Achua (2012:650) argues for self- regulation at the banking level, since government regulations enforce compliance to minimum social responsibility expectations. Social self-regulation at the banking level can enforce better conduct and promote social change in desirable directions, since those responsible for enforcement would have greater power and authority, better access to information and easier interpretation of violated rules. Achua (2012:65) further asserts that in a market economy where socially responsible business is no longer a one-size-fit all affairs, banks are increasingly aiming for a social beneficial bottom line instead of being prescribed to on how to get there. Self-regulation can promote financial soundness by embracing a broad consensus of all stakeholders' interests. For banks to be socially responsible, they need to establish structures that support social needs through various ways. The Prodere Programme (1997), in taking into account different objectives, environments and expectations, suggested that the development of CSR in the banking sector should consider the following: identification of various stakeholders, analysis of stakeholder expectation, designing appropriate products that meet identified stakeholder expectations, integration of objections of the bank with strategies and continuous review of the social system with changing social demands. Such a stakeholder approach will ensure that stakeholders are not marginalized, since all their needs are appropriately catered for. Further, by making banking society- oriented, banks invariably align their CSR programmes with their value statement. This can help to close the gap between stakeholder expectations and corporate governance, by focusing on empowering people, promoting innovation and improving efficiency which extends beyond mere compliance with regulations. By establishing CSR programmes as a self-regulation approach, specific attempts are therefore made to achieve maximum social outcomes.

Branco and Rodridgues (2006:236) used the legitimacy theory to argue that they need to disclose their social responsibility information since a "social contract" between business and society requires businesses like banks to present a socially responsible image. This is an important requisite since banks have to ensure that society, which allows them to exist and have rights, has expectations which must be fulfilled. When such expectations are not fulfilled, then the banks conduct in not in accordance with social values and norms, thereby breaching the principles of legitimacy. The legitimacy theory suggests that more popular banks have more reason to justify their existence to society by means of social responsibility disclosure. A study by Branco and Rodrigues (2006:245) suggest that banks with a higher visibility among consumers seem to exhibit greater concern to improve the corporate image through social responsibility information disclosure.

\section{Conclusion}

Banks in attempting to contribute to the common good of the local community, the country and humankind, have to engage in corporate social responsibility activities which satisfy the needs of all 
stakeholders. This necessitates a focus on investment in CSR rather than on increasing corporate wealth which is diminishing in importance against the landscape of organizational success. From the perspective of banks, the need is for a response process where issues can be recognised and plans developed to govern action, so that the banking sector can respond to social demands that impact on organizational success and sustainable growth.

\section{References}

Achua, J. K. (2012). Corporate social responsibility in Nigerian Banking system. Society and Business Review, 3(1), 57-71.

Ackerman, R. W. (1973). How companies respond to social demand. Harvard Business Review, 51(4), 8898.

Aggarwal, R. K. \& Youssef, T. (2003). Islamic banks and investment financing. Journal of Money, Credit and Banking, 32, 93-120.

Ali, I., Rehman, K. U., Ali, S. I., Yousaf, J. \& Zia, M. (2010). Corporate social responsibility influences, employee commitment and organizational performance. African Journal of Business Management, $4(12), 2796-2801$.

Argandona, A. (1998). The stakeholder theory and the common good. Journal of Business Ethics, 17, 10931102.

Belal, A. R. (2008). Corporate social responsibility in developing countries: The case of Bangladesh. Ashgate: Famham.

Branco, M. C. \& Rodrigues, L. L. (2006). Communication of corporate social responsibility by Portuguese banks: A legitimacy theory perspective. Corporate Communications: An International Journal, 11 (3), 232-248.

Carroll, A. B. (2000). Ethical challenges for business in the new millennium: Corporate social responsibility and models of management morality. Business Ethics Quarterly, 10(1), 33-42.

Cassel, D. (2001). Human rights and business responsibilities in the global marketplace. Business Ethics Quarterly, 11(2), 261-274.

Cowton, C. (2010). Banking. In J. Boatright (ed), Finance Ethics: Critical issues in financial theory and practice. New York: Wiley.

Dusuki, A. W. \& Abdullah, W. I. (2007). Why do Malaysian customers patronise Islamic banks? International Journal of Bank Marketing, 25(3), 142-160.

Farook, S., Hassan, M. K. \& Lanis, R. (2011). Determinants of corporate social responsibility disclosure. Journal of Islamic Accounting and Business Research, 2(2), 114-141.

Hu, V. \& Scholtens, B. (2012). Corporate social responsibility policies of commercial banks in developing countries. Sustainable Development, 2, 1-13.

Jamali, D. (2007). The case for strategic corporate social responsibility in developing countries. Business and Society Review, 112(1), 1-27.

Jamali, D. \& Mirshak, R. (2007). Corporate social responsibility: Theory and Practice in a developing country context. Journal of Business Ethics, 72(3), 243-262.

Joseph, F. \& Maria, S. J. (2012). CSR in Africa: Introduction to the special issue. African Journal of Economic and Management Studies, 3(1), 1-5.

Maali, B., Casson, P. \& Napier, C. (2003). Social reporting by Islamic Banking. Discussion papers in accounting and finance. Southampton: University of Southampton.

McDonald, L. M. \& Rundle-Thiele, P. (2008). Corporate social responsibility and bank customer satisfaction: A research agenda. International Journal of Bank Marketing, 26(3), 170-182.

Nkwankwo, G. O. (1991). Bank management: Principles and practice: Lagos: Malthouse Press Limited.

Nor, S. M. (2012). Integrating moral in a dynamic model of corporate social responsibility in Islamic Economics and Finance. Asian and African Area Studies, 11(2), 137-150.

Pomering, A. \& Donicar, S. (2006). Customer's sensitivity to different measures of corporate social responsibility in the Australian banking sector. Australia and New Zealand Marketing Academy Conference (ANZMAC), Brisbane, December 4-6.

Prodere Programme. (1997). More alternatives for access in the financial market: Social dimension of finance. Paper presented at Workshop Report - Employment Sector. Available at www.ilo.org/public/english/employment/ent/papers/workshop.htm. (accessed Jan 10, 2013).

Rahaman, A. S., Lawrence, S. \& Roper, J. (2004). Social and environmental reporting at the VRA: Institutional legitimacy or legitimation crisis? Critical Perspectives on Accounting, 15(1), 35-56.

San-Jose, L., Retolaza, J. L. \& Gutierrez-Goiria, J. (2011). Are ethical banks different? A comparative analysis using the radical affinity index. Journal of Business Ethics, 100, 151-173. 
Scholtens, B. (2008). Corporate social responsibility in the international banking industry. Journal of Business Ethics, 86,159-175.

Sen, S. \& Bhattacharya, C. B. (2001). Does doing good always lead to doing better? Consumer reaction to corporate social responsibility. Journal of Marketing Research, 38, 225-243.

Smurthwaite, M. (2011). Business ethics as field of training, teaching and research in Southern Africa. African Journal of Business Ethics, 5(2), 81-150.

Tantawi, P. \& Youssef, A. (2012). The importance of corporate social performance in place branding of retail banks in Egypt. African Journal of Economic and Management Studies, 3, 77-94.

Teoh, H. \& Shiu, G. (1990). Attitudes towards corporate social responsibility and perceived importance social responsibility information characteristics in a decision context. Journal of Business Ethics 9, 71-77.

Usmani, M. T. (2002). Corporate Social responsibility underlines values propagated by Islam. Kuala Tumpur: Bernama.

Wahba, H. (2008). Exploring the moderating effect of financial performance on the relationship between corporate environmental responsibility and institutional investors: Some Egyptian evidence. Corporate Social Responsibility and Environmental Management, 15, 361-371.

World Business Council for Sustainable Development. (2001). The business case for sustainable development: Making a difference towards the Johannesburg Summit 2002 and beyond. Available: http://www.wbcsd.org. (online) Date accessed: 2 December 2012. 